\title{
Pharmacognostical studies on Oxystelma esculentum (L.F) R. Br. ex Schltes, a medicinal plant
}

\author{
G. Savitha, S. Balamurugan* \\ Department of Botany, Annamalai University, Annamalai Nagar, India \\ *E-mail address: drbalu2011@gmail.com
}

\begin{abstract}
The present investigation has been carried out to study the anatomical features of root, rhizome, stem, leaf and petiole for evaluating the Oxystelma esculentum, an important medicinal plant used in the traditional systems of medicine. This study provides referential pharmaco-botanical information for correct identification of this plant.
\end{abstract}

Keywords: Pharmacognosy; physico-chemical; Oxystelma esculentum

\section{INTRODUCTION}

Oxystelma esculentum (L.F) R.Br. ex Schltes is an important medicinal plant belonging to the family Asclepiadaceae used in the traditional systems of medicine for various ailments. The plant is hot, bitter, tonic, expectorant, pungent, dry and indigestible; causes flatulence, diuretic, laxative, aphrodisiac, anthelmintic, useful in leucoderma and bronchitis. The juice is used in gleet, gonorrhea, pain in the muscles, cough and given to children as an astringent. The milky sap forms a wash for ulcers. In combination with turpentine it is prescribed for itch [1]. Oxystelma esculentum is reported to possess antiseptic, depurative and galactagogue properties. A decoction of the plant is useful as a gargle in infections of throat and mouth. [23]. The present study has been carried out to study the anatomical features of leaf, stem, petiole, roots and rhizome to serve as a possible tool for proper identification of Oxystelma esculentum.

\section{MATERIAL AND METHODS}

\section{1. Collection and authentification of the plant}

Oxystelma esculentum (L.F) R.br. Ex Schltes was collected in the flowering and fruiting stage from Annamalai University campus, Annamalainagar during the month of July 2013. Herbarium of the collected sample was prepared and deposited in the Department of Botany, Annamalai University. Authentification was done by Dr. V. Venkatesalu, Head of the Department of Botany (DDE), Annamalai University.

\section{2. Pharmacognostical studies}

Fresh samples of leaf, petiole, stem, root and rhizome were used for pharmacognostical studies and quantitative microscopy. The plant samples were fixed in FAA (95\% Formalin- 5 
$\mathrm{ml}+95 \%$ Acetic acid- $5 \mathrm{ml}+70 \%$ Ethyl alcohol $90 \mathrm{ml}$ ). After $24 \mathrm{hrs}$ the materials was washed thoroughly (Weswox TM Optik, Model MT- 1090A) section was taken, and stained with safranin according to the prescribed methods [4]. Photographs were taken by Phase contrast microscope (Olympus SP-350, digital compact camera, 8.0 mega pixels).

Physicochemical studies like determination of ash values [5], $\mathrm{PH}$ of aqueous solution, extractive values [6]. Phytochemical studies like Cardenolides [7], Phenolics [8], Flavonoids [9] and Sugars [10].

\section{RESULTS AND DISCUSSION}

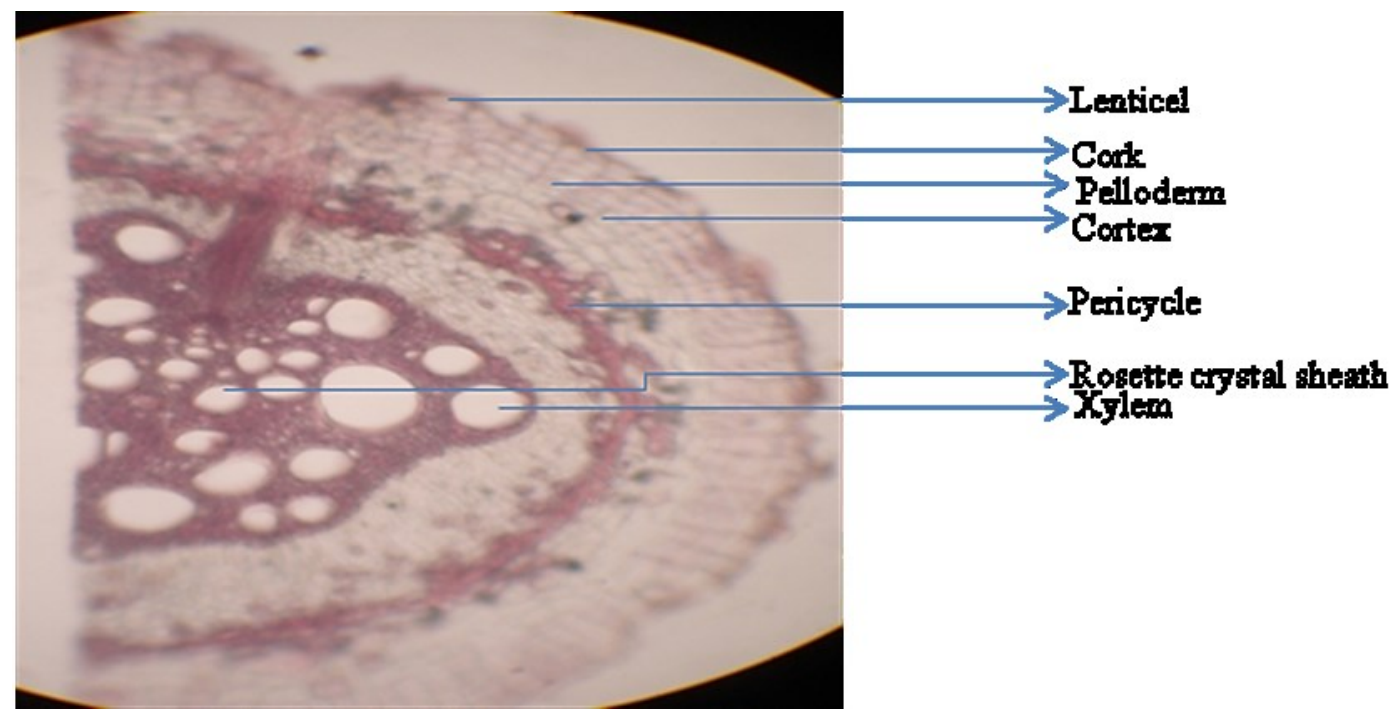

Fig. 1. Transverse section of root.

Figure showing calcium oxalate crystals

Oxystelma esculentum has tremendous medicinal potential owing to its multifaceted biological functions. However, there are no detailed pharmacognostic studies to help in the proper identification. Hence the present study carried out to provide key diagnostic tools of identification. The following anatomical features can be used to diagnose this plant. 
Druses type of calcium oxalate crystals are present and starch grains are absent in the cortex region. Vessel elements circular in outline, wide, tailed with simple pits, simple peroration plates, arranged in diffuse porous with pores solitary (Fig. 1).

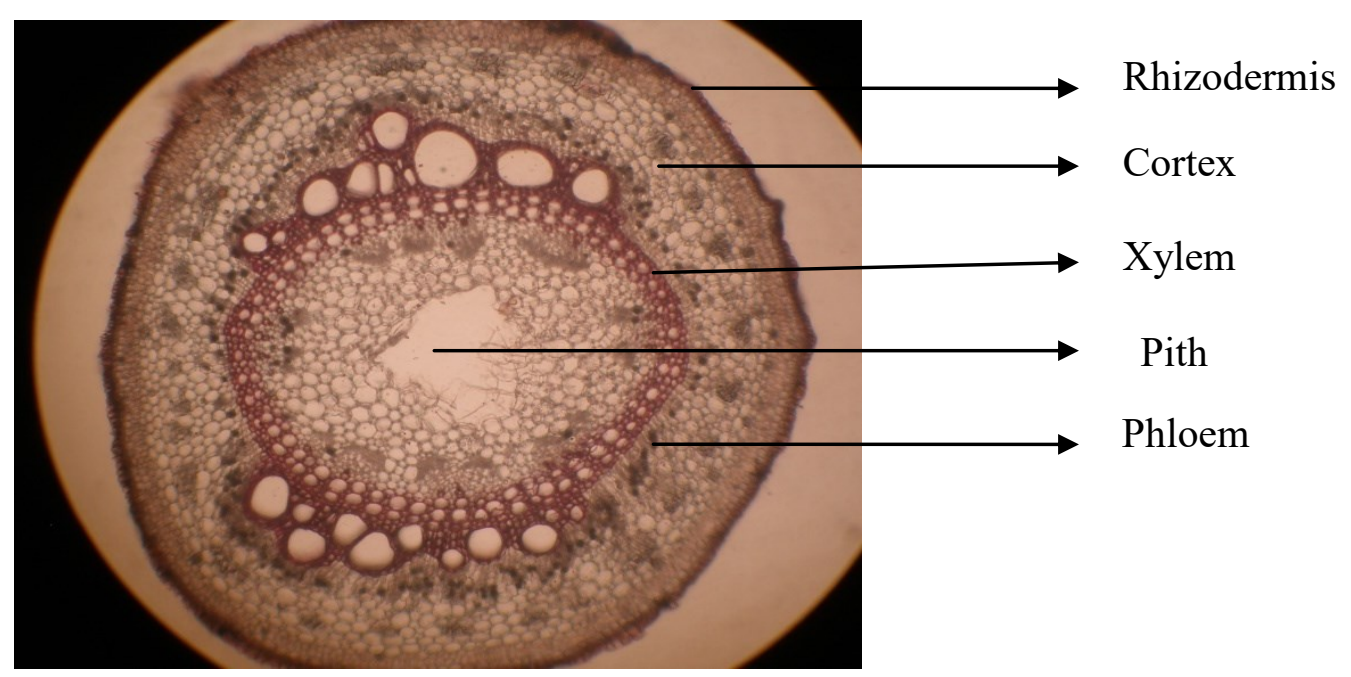

Fig. 2. Transverse section of rhizome.

Epidermal cells large in size and radially elongated. Cortex with abundant starch grains and druses type of calcium oxalate crystals. Xylem elements mostly with fibers and tracheids (Fig. 2).

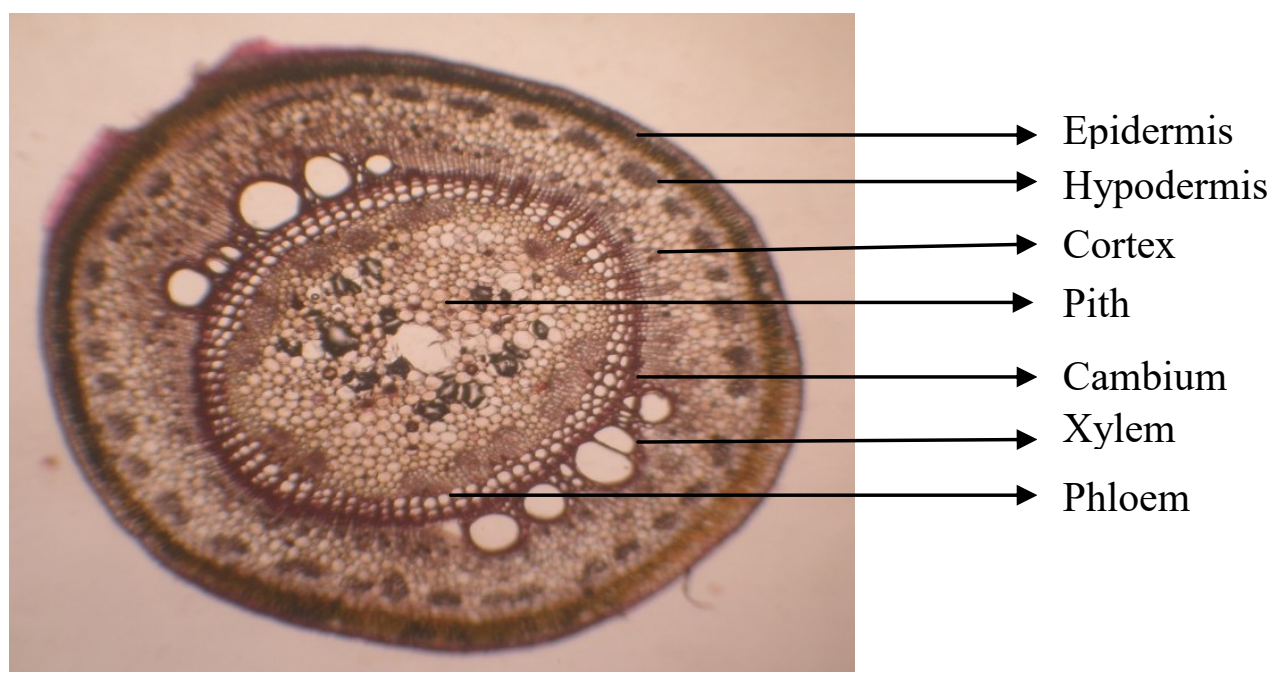

Fig. 3. Transverse section of stem.

Abundant druses type of calcium oxalate crystals and phloem and fibres in the cortex or pentagonal shape of secondary xylem. Vessels are solitary, wide short, circular or oval outline, barrel, shaped, with simple pits, simple perforation plate and without tail (Fig. 3). 

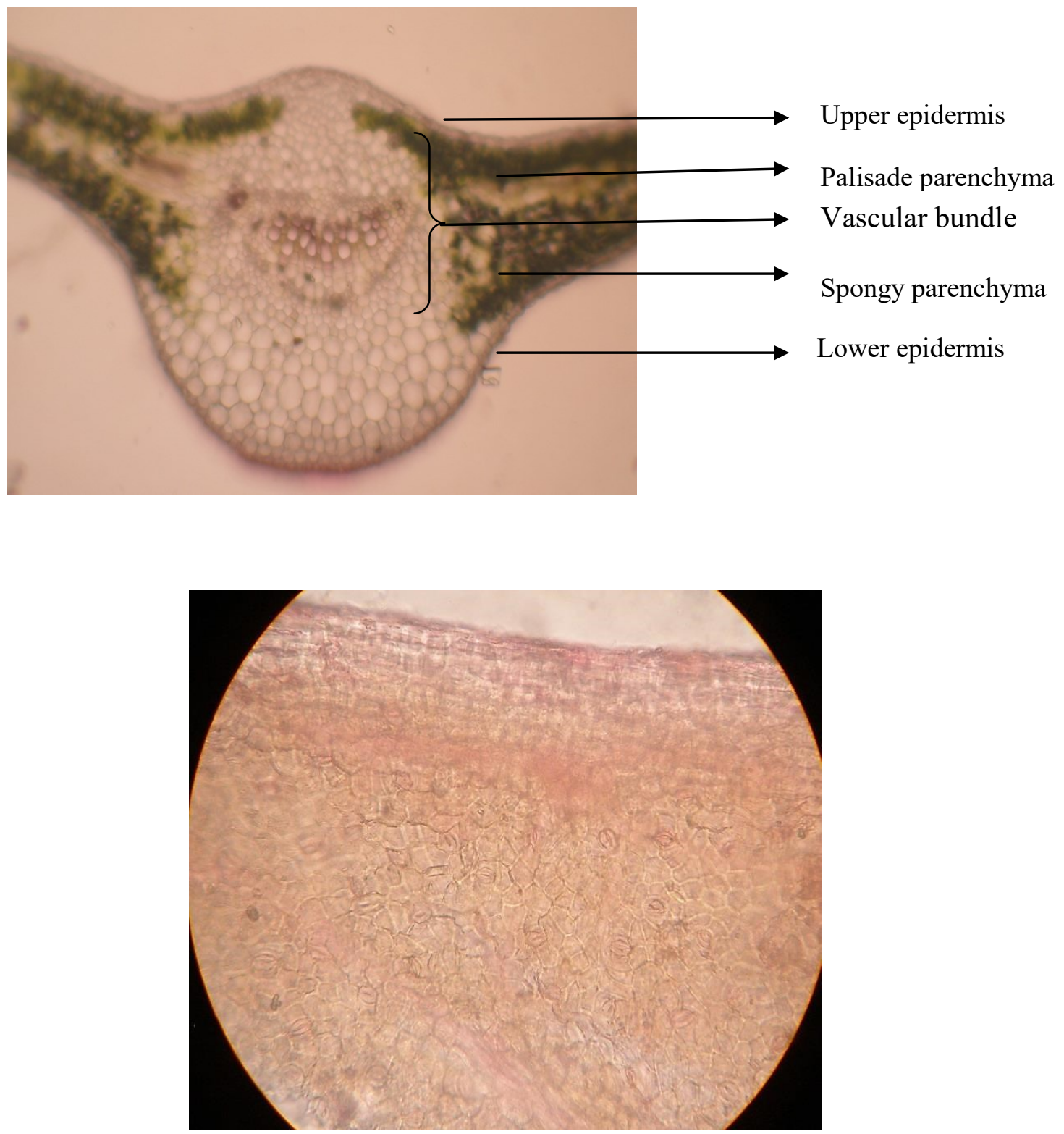

Figure showing anomocytic stomata

Fig. 4. Transverse section of leaf.

Stomata are amphistomatic and anomocytic type. Druses type of calcium oxalate crystals in mesophyll (Fig. 4). 


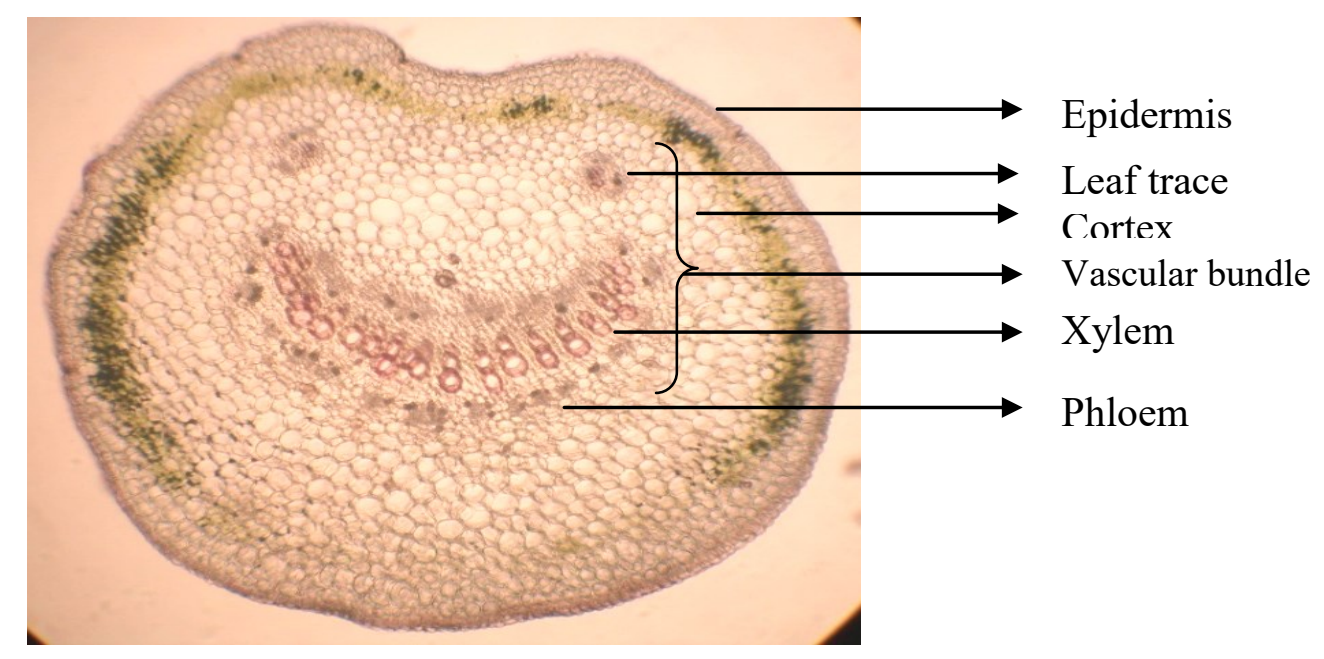

Fig. 5. Transverse section of petiole.

Circular in outline, vascular bundle open type; three vascular bundles, arrangement is 1+2; dorsal bundle large bowl shaped and laterals small circular. Vascular bundle surrounded by druses type of calcium oxalate crystals.

Table 1. Physico-chemical analyses.

\begin{tabular}{|c|c|}
\hline Parameters & \% w/w \pm SD \\
\hline Loss of drying & $70.21 \pm 0.50$ \\
\hline Ash values & $10.21 \pm 0.24$ \\
Total ash value & $0.76 \pm 0.20$ \\
Acid insoluble ash & $6.15 \pm 0.21$ \\
Water soluble ash & \\
\hline Extractive values & $4.2 \pm 0.17$ \\
Water soluble extractive & $2.2 \pm 0.15$ \\
Alcohol soluble extractive & \\
\hline
\end{tabular}

Physico-chemical determination of water soluble extractives were greater than those of alcohol soluble extractives, indicating the presence of water soluble phytoconstituents in higher amounts in this plant (Table 1).

\section{1. Phytochemical studies}

Phytochemical screening was performed (Table $2 \& 3$ ) estimation of phytoconstituents included that of cardenoliedes, phenolics, flavonoids and sugars are present. 
Table 2. Phytochemical screening.

\begin{tabular}{|c|c|c|}
\hline Phytoconstituent & Test & Result \\
\hline Alkaloids & $\begin{array}{l}\text { Dragenorff's test } \\
\text { Wagner's test } \\
\text { Mayer's test } \\
\text { Hager's test }\end{array}$ & $\begin{array}{l}\text {-ve } \\
\text {-ve } \\
\text {-ve } \\
\text {-ve }\end{array}$ \\
\hline Flavonoids & $\begin{array}{c}\text { Shinoda test } \\
\text { Lead acetate test }\end{array}$ & $\begin{array}{l}+\mathrm{ve} \\
+\mathrm{ve}\end{array}$ \\
\hline Sterols & $\begin{array}{c}\text { Salkowski test } \\
\text { Libermann buchart test }\end{array}$ & $\begin{array}{l}+ \text { ve } \\
+\mathrm{ve}\end{array}$ \\
\hline Cardiac glycosides & $\begin{array}{c}\text { Legal's test } \\
\text { Bajlet test } \\
\text { Keller killiani test } \\
\text { Kedde's test }\end{array}$ & $\begin{array}{l}+ \text { +ve } \\
+ \text { ve } \\
+ \text { ve } \\
+ \text { ve }\end{array}$ \\
\hline Saponin glycosides & $\begin{array}{c}\text { Foam test } \\
\text { Lead acetate test }\end{array}$ & $\begin{array}{l}\text {-ve } \\
\text {-ve }\end{array}$ \\
\hline Phenolics & $\begin{array}{l}\text { Ferric chloride test } \\
\text { Folin cioealteu test }\end{array}$ & $\begin{array}{l}+ \text { ve } \\
+ \text { ve }\end{array}$ \\
\hline Sugars & $\begin{array}{l}\text { Fehling's test } \\
\text { Molisch test }\end{array}$ & $\begin{array}{l}+ \text { ve } \\
+ \text { ve }\end{array}$ \\
\hline Gums & Ruthenium red test & -ve \\
\hline
\end{tabular}

Table 3. Estimation of phytoconstituents.

\begin{tabular}{|c|c|}
\hline Phytoconstituents & \% w/w $\mathbf{E S D}$ \\
\hline Cardenolides & $0.94 \pm 0.12$ \\
Phenolics & $1.23 \pm 0.14$ \\
Flavonoids & $0.42 \pm 0.12$ \\
Sugars & $2.14 \pm 0.13$ \\
\hline
\end{tabular}




\section{CONCLUSIONS}

A detailed study of roots, rhizome, stem, leaf and petiole of Oxystelma esculentum was performed. Microscopic study revealed the presence of diagnostic features like cork in surface view, parenchymatous tissue having large number of calcium oxalate rosette crystals and xylem vessels with different types of thickening. Various quantitative microscopic parameters and physico-chemical parameters were established. Values of water soluble extractives were greater than those of alcohol soluble extractives, indicating the presence of water soluble phytoconstituents in higher amounts. Cardenolides, phenolics, flavonoids and sugars were detected by a thorough phytochemical screening procedure and they were estimated by their respective methods. This indicates that the plant can be useful for treating different diseases, especially those related to the cardiovascular system, as the therapeutic activity of a plant is always due to the presence of particular class of phytocompounds. The present study can serve as a useful gauge in the identification, authentication and standardization of the plant material as well as investigating its phytochemical composition, which would help in investigation of its possible pharmacological actions.

\section{References}

[1] Kirtikar K.R., B.D. Basu, (1976). Indian medicinal plants. International book Distributors, Dehradun, India.

[2] Chopra R.N., I.C. Chopra, K.L. Handa, L.D. Kapoor, (1958). Indigenous Drugs of India. Academic publishers, Calcutta, India.

[3] Nadkarni A.K. (1982). Indian Materia Medica, Popular Parkashan Pvt. Ltd., Mumbai.

[4] Sass J. E. (1940). Elements of Botanical Microtechnique. New York: McGraw-Hill Book Co.

[5] Anonymous (1980). AOAC, Official Methods, of Analysis, 14 th Edition Washington D.C.

[6] Anonymous. British Pharmacopoiea. London: General Medical Council Pharmaceutical Press 17 (1968) 1209, 1227, 1267, 1268, 1276.

[7] Department of Health. British Pharmacopoeia. Vol. I. London (United Kingdom): HMSO; 1993.

[8] World Health Organization. Quality Control Methods for Medicinal Plant Materials. Geneva (Switzerland): WHO; 2002.

[9] Baharam T, Gressier B, Trotin F, Brunet C, Dine T, Pinkash M., Drug Res. 46(6) (1996) 1086-1089.

[10] Hodge J.E., Hofreiter B.T., Determinations of reducing sugars and carbohydrates analysis. In: Roy LW, Wolfrom ML, Editors. Methods in carbohydrate chemistry. Vol. I. London: Academic Press, p. 388-405; 1962. 